\title{
Demographic Aging In The United States: Implications For Population And Income Redistribution To The Year 2000
}

\author{
William J. Serow and Michael A. Spar*
}

\section{INTRODUCTION AND METHODOLOGICAL SUMMARY}

The purpose of this paper is to analyze the effects of a prolonged period of sustained low fertility upon shifts in the population distribution of the United States among Department of Energy (DOE) regions. For purposes of simplicity, the assumption is made that the Series III projections of the U. S. Bureau of the Census (1977) will hold over the projection period. The assumptions underlying this projection are: a) an ultimate level of completed cohort fertility (average number of lifetime births per woman) of 1.7 ; b) increase of life expectancy from 69.1 (1976) to 71.8 years (2050) for men and from 77.0 to 81.0 years for women; c) net immigration of 400,000 per year. The population of the year 2000 will be the focal point of this research.

Under these conditions, migration will emerge as the primary agent for internal population redistribution. The tack which will be taken here will be to divide migration into economic (employment) and non-economic aspects. While the latter is important, treatment of it here will be essentially exogenous - that is, projections of migration for causes such as retirement, college attendance, and military service will be based only upon an extrapolation of recent age-specific trends. Thus, changes in the relative size of these migration streams will reflect changes in the national age and sex composition.

Employment based migration though will be approached from an analytical perspective. Changes in the industrial composition of the nation's labor force will be derived from projected changes in income and consumption patterns resulting from the advent of sustained low fertility. This nationwide composition will then be decomposed in light of recent trends in the regional distribution of employment by industry. Hence, it will be feasible to derive inter-regional shifts in employment and interregional employment related migration.

This result, coupled with the previous statements about non-economic migration, provides a complete portrayal of migration differentials among regions. This then permits a portrayal for the year 2000 of the population

*Department of Economics and Center for the Study of Population, Florida State University; and Tayloe Murphy Institute, University of Virginia, respectively. 


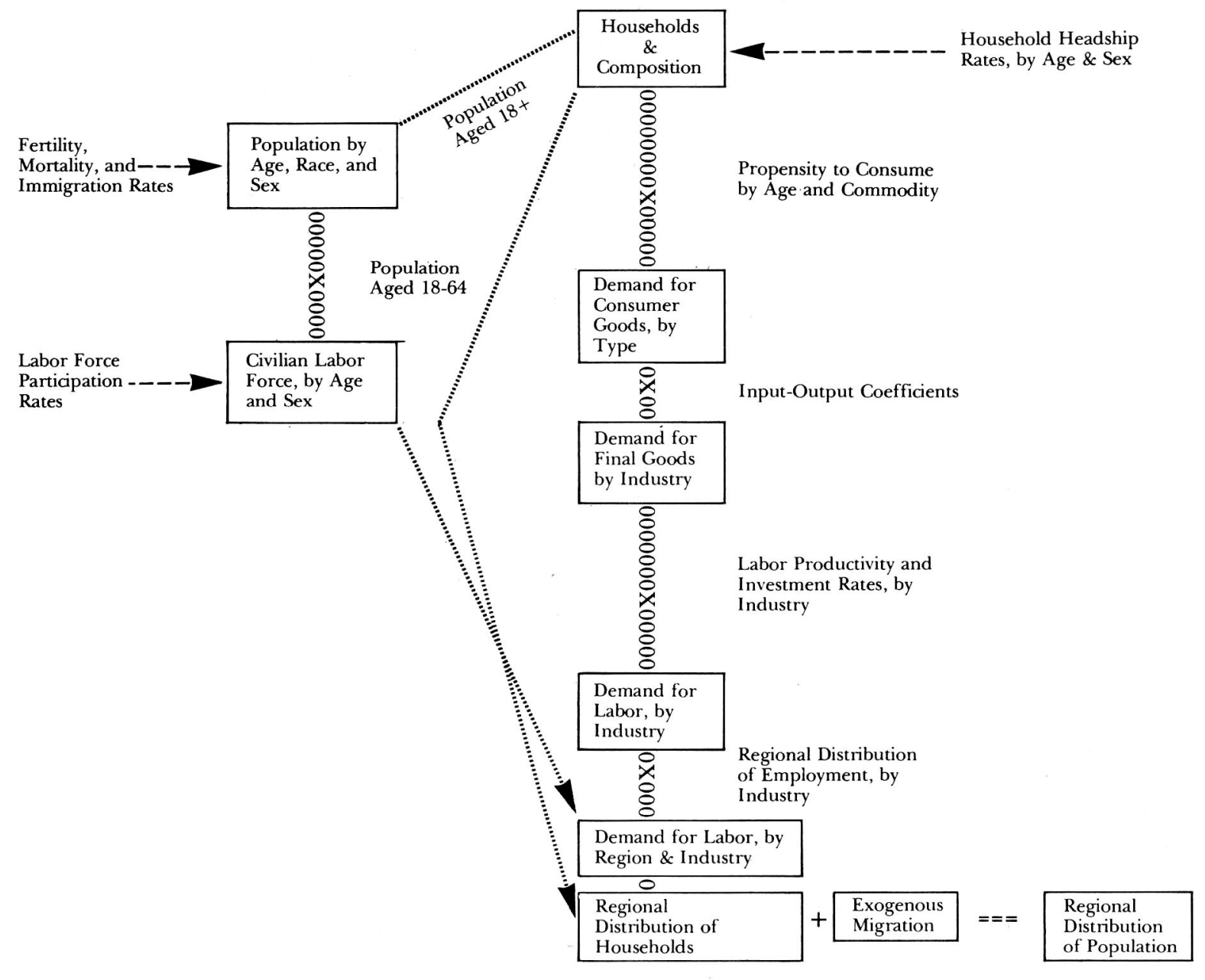


of DOE regions by basic demographic and labor force characteristics (age, race, sex, income, labor force participation) as well as an identification of which (if any) regions will experience particular economic problems during the period.

The basic methodology of the economic projections is outlined in Figure 1. The Series III population projections make, as noted above, explicit assumptions regarding fertility, mortality, and net immigration. Labor force participation rate projections are adapted from those prepared for 1990 by the Bureau of Labor Statistics (Fullerton and Flaim, 1976). In essence, these show declining participation among men at all ages over 20, with particularly sharp declines after age 55. Participation rates among women, however, are forecast to rise for all ages up to 64 . No change in these rates is assumed after 1990. The full detail is shown in Table 1.

Po ulation projections also permit the derivation of the projection of the number of households, by age of head. The 1995 projections of the $U$. $\mathrm{S}$. Bureau of the Census (1979b) are extended to the year 2000 for this purpose. (This set of age specific rates is also used to derive projections of the number of households for DOE regions.) These coupled with assumptions regarding the level of earnings and spending patterns, by age of head, permits the projection of the demand for consumer goods (Serow, 1981). Through application of input-output models, these results are transformed into a distribution of total demand.

To convert demand for goods and services into demand for labor, by industrial sector, it is necessary to make assumptions regarding future levels of labor productivity and investment behavior. The assumption is made here that post-war industry specific trends will continue. This may seem surprising in light of the great attention paid to productivity problems of American industry over the past few years. However, demographic

TABLE 1.

Givilian Labor Force Participation Rates by Age and Sex: 1975 and 1990

(percent)

\begin{tabular}{llrrrr}
\hline & & Male & & Female & \\
& 1975 & 1990 & 1975 & 1990 \\
\hline $16-19$ & 59.1 & 61.3 & 49.1 & 55.2 \\
$20-24$ & 84.4 & 82.1 & 64.0 & 75.2 \\
$25-34$ & 95.1 & 94.7 & 54.5 & 63.5 \\
$35-44$ & 95.7 & 94.8 & 55.9 & 63.0 \\
$45-54$ & 92.0 & 90.2 & 54.6 & 60.3 \\
$55-64$ & 75.7 & 69.9 & 41.0 & 42.3 \\
$65+$ & 21.7 & 16.8 & 8.2 & 7.6 \\
Total & 77.8 & 77.3 & 46.3 & 51.4 \\
\hline
\end{tabular}


changes in the coming two decades will produce a labor force somewhat older and more experienced than that of the 1970s. In addition, the proportion of new entrants in the labor force will be much lower in the 1980 s and 1990s than was true in the 1970s. Both of these factors suggest an improved outlook for productivity and investment for the remainder of the century.

The final demand for labor, by industrial sector, is then decomposed into a regional distribution, by assuming the continuation of the 1950 to 1970 trend in this industry-specific distribution. Implicitly, therefore, industries which have been concentrating in a particular region in the past are projected to continue to do so in the future. Such an assumption is not

\section{TABLE 2.}

Projected Distribution of Demand for Labor (in percent, except for total)

\begin{tabular}{lcc}
\hline & 1975 & 2000 \\
\hline Total (millions of persons) & 84.8 & 133.6 \\
Agriculture, Forestry and Fisheries & $4.1 \%$ & $1.7 \%$ \\
Mining & 0.9 & 0.7 \\
Construction & 5.9 & 3.6 \\
Manufacturing & $(22.7)$ & $(25.3)$ \\
Food and Tobacco & 2.2 & 1.3 \\
Textiles and Apparel & 2.6 & 1.9 \\
Lumber and Furniture & 1.4 & 1.7 \\
Paper and Publishing & 2.2 & 2.5 \\
Chemicals & 1.3 & 1.4 \\
Petroleum & 0.3 & 0.2 \\
Rubber & 0.8 & 1.0 \\
Leather & 0.4 & 0.3 \\
Stone, Glass and Clay & 0.8 & 0.7 \\
Primary Metals & 1.6 & 3.3 \\
Fabricated Metals & 1.8 & 2.3 \\
Non-Electric Machinery & 2.7 & 3.2 \\
Electric Machinery & 2.3 & 2.1 \\
Transport Equipment & 2.5 & 3.4 \\
Transportation, Communication & & \\
and Utilities & 6.6 & 6.3 \\
Trade & 20.6 & 18.6 \\
Finance, Insurance, Real Estate & 5.5 & 7.1 \\
Business Services & 3.3 & 3.8 \\
Personal and Other Services & 4.3 & 6.0 \\
Professional Services & 11.2 & 13.3 \\
Government & 13.7 & 13.6 \\
\hline
\end{tabular}

Source of basic data: Employment and Earnings, March 1977. 
as simplistic as it may appear, for increasing concentration not only permits a greater achievement of economies of scale, but also recognizes the real existence of a built-in momentum toward regional growth, which, once firmly established, becomes difficult to reverse-we make no assumptions regarding federal policies designed to thwart this momentum. The reasons for, say, the past growth of the South or West may well have been lower wages, the existence of right to work laws, and the like. However, as growth has transformed the industrial map of the nation, the reasons for the probable continuation of the "Sunbelt" drift are more likely to be the supply of labor and access to growing markets.

In the year 2000, we assume that regional labor markets will be cleared - that is, there has been sufficient interregional mobility of labor so that relative growth of a region's labor supply is reflected by its relative growth in employment opportunities. From this result stems projections of the household (civilian, non-college) population, with head under age 55 . Variations in the age composition of regions will reflect the age composition of a region's labor force. Thus, regions with comparatively large concentration of employment in industries favored by younger workers will have comparatively young populations, due not only to the greater presence of younger workers, but also because they are likely to have young children. Thus, regional differences in overall fertility are not the result of regional variation in age-specific fertility, but rather are the consequence of regional differences in age composition.

To this employment-based projection of population distribution are added exogenous projections of those segments of the population whose mobility is not motivated by economic considerations. The most readily identifiable of these are persons aged 55 and over, those in the military, and those in college. This distribution is taken from recent U. S. Bureau of the Census (1979a) projections. By and large, the analysis is carried out for Department of Energy (DOE) regions.

\section{REGIONAL CHANGES IN THE DEMAND FOR LABOR}

Changes in the demand for labor in a given industry are determined by the change for its output divided by its productivity index plus net replacement demand, all multiplied by a scalar factor equal to unity plus net exports of the industry as a percentage of total domestic production of the industry. The combination of these forces leads to the projection of demand for labor, by industrial sector, shown in Table 2.

Projections of the geographic distribution by employment, by industry, are based upon an extrapolation of post World War II trends in this distribution (Ashby and Cartwright, n.d.) From this data and the result presented in Table 2, one is able to project total and industry-specific employment totals for the year 2000 . These are presented in Table 3. This result is the result of the interaction of: a) the assumption of continuation of recent trends in the distribution of employment by industry, with b) the changes in the pattern of the industrial demand for labor consistent with a prolonged period of sustained low fertility. 
TABLE 3.

Projected Employment by Industry and Region: 2000 (millions)

\begin{tabular}{|c|c|c|c|c|c|c|c|c|c|c|c|c|c|}
\hline & I & II & IIIA & IIIB & III & IV & V & VI & VII & VIII & IX & $\mathrm{X}$ & Total \\
\hline Agriculture & .08 & .12 & .08 & .06 & .14 & .22 & .40 & .24 & .32 & .19 & .42 & .14 & 2.27 \\
\hline Mining & .01 & .03 & .03 & .14 & .17 & .07 & .09 & .27 & .03 & .08 & .17 & .02 & .94 \\
\hline Construction & .32 & .36 & .26 & .43 & .69 & 1.12 & .88 & .58 & .21 & .09 & .43 & .13 & 4.81 \\
\hline Food Manufacturing & .03 & .10 & .09 & .09 & .17 & .37 & .38 & .21 & .15 & .05 & .17 & .09 & 1.74 \\
\hline Textiles & .07 & .19 & .27 & .27 & .54 & 1.61 & .10 & .16 & .05 & .03 & .17 & .09 & 2.94 \\
\hline Lumber \& Furniture & .10 & .08 & .14 & .14 & .28 & .73 & .40 & .21 & .08 & .01 & .16 & .22 & 2.27 \\
\hline Chemicals \& Petroleum & .19 & .72 & .15 & .28 & .43 & .59 & .66 & .37 & .16 & .02 & .31 & .02 & 3.47 \\
\hline Paper \& Publishing & .21 & .36 & .17 & .21 & .38 & .55 & .98 & .24 & .15 & .06 & .33 & .08 & 3.34 \\
\hline Stone, Glass, Clay & .08 & .10 & .06 & .04 & .10 & .11 & .14 & .25 & .08 & .04 & .11 & .01 & .94 \\
\hline Primary Metals & .20 & .21 & .55 & .13 & .68 & .47 & 1.86 & .37 & .15 & .05 & .29 & .13 & 4.41 \\
\hline Fabricated Metals & 15 & .15 & .15 & .08 & .23 & .48 & 1.02 & .36 & .22 & .02 & .29 & .10 & 3.07 \\
\hline Non-Elęctric Machinery & .21 & .34 & .22 & .17 & .39 & .59 & 1.45 & .33 & .22 & .12 & .56 & .06 & 4.28 \\
\hline Electric Machinery & .16 & .23 & .11 & .16 & .27 & .50 & .51 & .45 & .16 & .07 & .46 & .06 & 2.81 \\
\hline Transport Equipment & .28 & .09 & .18 & .13 & .31 & .79 & 1.57 & .57 & .24 & .09 & .41 & .18 & 4.54 \\
\hline \multicolumn{14}{|l|}{ Transportation \& } \\
\hline Communication & .40 & 1.23 & .29 & .49 & .78 & 1.46 & 1.35 & .77 & .41 & .19 & 1.54 & .30 & 8.42 \\
\hline Trade & 1.63 & 2.32 & 1.06 & 1.27 & 2.33 & 3.90 & 5.13 & 2.26 & 1.25 & .69 & 3.93 & .89 & 24.32 \\
\hline Finance & .60 & 1.36 & .36 & .55 & .91 & 1.52 & 1.51 & .99 & .46 & .22 & 1.54 & .41 & 9.49 \\
\hline Business Services & .26 & .74 & .21 & .29 & .50 & .78 & .84 & .51 & .20 & .11 & .98 & .17 & 5.08 \\
\hline Personal Services & .35 & .63 & .27 & .46 & .73 & 1.26 & 1.40 & .80 & .45 & .27 & 1.80 & .31 & 8.02 \\
\hline Professional Services & 1.15 & 2.01 & .75 & 1.11 & 1.86 & 2.67 & 3.36 & 1.68 & .78 & .53 & 2.62 & .58 & 17.32 \\
\hline Government & .63 & 1.56 & .51 & 2.73 & 3.24 & 3.30 & 2.09 & 1.72 & .68 & .86 & 2.99 & .56 & 17.64 \\
\hline Total & 7.11 & 12.99 & 5.91 & 9.22 & 15.13 & 23.09 & 26.12 & 13.34 & 6.39 & 3.79 & 19.68 & 4.49 & 133.60 \\
\hline
\end{tabular}


TABLE 4.

Projected Distribution of Civilian, Non-College Population,

by Age and Region: 2000

(percent of national total)

\begin{tabular}{lcccccc}
\hline & $0-9$ & $10-17$ & $18-24$ & $25-34$ & $35-44$ & $45-54$ \\
\hline I & .0543 & .0535 & .0546 & .0539 & .0543 & .0526 \\
II & .1005 & .0976 & .1016 & .0994 & .0985 & .0967 \\
IIIA & .0447 & .0442 & .0446 & .0450 & .0437 & .0447 \\
IIIB & .0682 & .0722 & .0666 & .0696 & .0715 & .0730 \\
III & .1129 & .1165 & .1112 & .1146 & .1152 & .1177 \\
IV & .1734 & .1752 & .1727 & .1741 & .1753 & .1751 \\
V & .2012 & .1995 & .2004 & .2020 & .1999 & .1991 \\
VI & .1003 & .1007 & .0996 & .1009 & .1009 & .1005 \\
VII & .0478 & .0471 & .0481 & .0474 & .0464 & .0478 \\
VIII & .0276 & .0286 & .0276 & .0275 & .0283 & .0289 \\
IX & .1483 & .1477 & .1499 & .1466 & .1475 & .1478 \\
X & .0340 & .0337 & .0344 & .0335 & .0337 & .0337 \\
\hline
\end{tabular}

'These data also permit one to make inferences regarding the national distribution of the population under age 55 excluding military and college students. This is accomplished by assuming that the 1970 relative age composition among industries remains constant over time. Thus, the age composition of regions will change not only as a result of changes in the national age composition, but also as a result of change in the region's industrial structure. This procedure permits a projection of the civilian, non-college population in the following age groups: 18-24, 25-34, 35-44, and 45-54. To this can be added projections of the 0-9 and 10-17 population. It may be reasonably assumed that persons in this age group will be located in regions in about the same proportion as are their parents. Thus, the regional distribution of the $0-9$ population will be taken to be the same as the average of the 18-24 and 25-34 populations, and that of the 10-17 population will be the average of the $35-44$ and $45-54$ populations. The results of these procedures are summarized in Table 4 .

Thus far, we have not accounted for the distribution of that portion of the population whose mobility behavior is not economically motivated. While the most common view of migration is that it is related to jobseeking, job-transfer or some similar employment based concern, other motivations accounted for nearly half the interstate moves reported by persons in the Annual Housing Surveys of 1974, 1975 and 1976 (Long and Hansen, 1979, pp. 5-8). (Table 5).

There are clearly striking differences by age in the motivations for migration. This is most notable among persons aged 55 and over, where retirement, desire for a climate change (perhaps related to impending retirement), and family reasons (most often a desire to live closer to relatives) account for about two thirds of all moves. For young persons, 
TABLE 5

Motivation for Interstate Migration of Household heads, by Age, 1974-1976 (percent)

\begin{tabular}{lrrrr}
\hline & Total & $20-34$ & $35-54$ & $55+$ \\
\hline Job & 50.8 & 55.7 & 57.2 & 13.5 \\
Military & 4.8 & 6.3 & 2.6 & 0.0 \\
College & 5.4 & 7.5 & 1.2 & 0.4 \\
Climate & 5.1 & 3,2 & 5.8 & 12.1 \\
Retirement & 3.4 & 0.0 & 3.3 & 19.8 \\
Family & 17.3 & 13.4 & 15.2 & 33.4 \\
Other, not reported & 13.2 & 12.9 & 14.2 & 20.6 \\
\hline
\end{tabular}

Source: Long and Hansen, 1979.

employment and the employment-related categories of military service and school attendance account for two thirds or more of all moves.

Despite their relatively small shares of overall migration motivation, one should not discount the importance of these non-employment migration streams. During the 1960 s, for example, military and college moves frequently have substantial effects on the volume of net migration recorded for states (Serow, 1976; Long, 1976; Steahr and Lowe, 1975). Similarly, migration of older persons, while being a reaction to quite different motivations, also plays a not insignificant role in some migration streams (Barsby and Cox, 1975; Serow, 1978; Longino, 1979).

In the remainder of the twentieth century, the importance of these and similar migration streams (particularly that of college students) will change as the age composition of the population changes in response to sustained low fertility. This paper will treat the effects in the United States of sustained fertility at the ultimate level of 1.7 children ever born per woman. This will imply substantial demographic change in terms of age and sex composition. As a result of these changes, the comparative importance of migration streams heavily comprised of younger persons should diminish, while that of migration streams heavily comprised of older persons should increase.

Particular attention should be devoted to changes in the relative sizes of the three age groupsidentified in Table 5. The 20-34 group is projected to decline in absolute size by 3.4 percent from 1976 to 2000 , while the 35 to 54 and 55 and over groups should increase by 65.3 and 28.1 percent, respectively (overall increase in population under the assumptions noted above will be 14.6 percent). It is important to realize that, except for the youngest members of the 20-34 age group, these changes are not functions of fertility levels between the present and the end of the century. Rather, these changes represent the aging of persons already alive and may be taken as more or less fixed. 
As noted above, the approach taken here will be to assume that noncivilian employment migration will be exogenously determined. As is clear from Table 5, retirement, climate and family oriented migration and not employment represent the largest forces in determining migration trends, and hence changes in the inter-regional distribution of the older population. In light of any evidence to the contrary, therefore, the Series A projections of the U.S. Bureau of the Census (1979a) are accepted for the population aged 55 and over in the year 2000. This projection assumes a continuation from 1975 to 2000 of civilian non-college interstate migration by age, race, and sex observed for the period from 1965 to 1975 .

Projections of military personnel by state of residence (while in military service) have also been prepared by the U. S. Bureau of the Census (1979a)-these are simply the distribution which existed in 1975, with no net change assumed to occur over the final quarter of the century. Since changes in the absolute size and geographic distribution of military personnel are based on defense policy changes, there seems to be no apparent basis to make assumptions contrary to those of the Census Bureau.

Similar extrapolations are used to obtain a projected distribution of college students by region of residence. The total number of students is merely based on the national number of persons aged 18-24 and the current rate of college attendance of these persons. While it is clear that persons above this age group are attending college in increasingly greater numbers (U. S. Bureau of the Census, 1979c), the interest here is on the inter-regional population effects. Such older students are very likely to be working full time and attending classes on nights or on weekends-hence their migration behavior is best captured in the employment based migration which follows. Out treatment of the redistributional effects is limited to an extrapolation of observed 1965-1970 trends in migration for fulltime college attendance (U. S. Bureau of the Census, 1973b). Again, there seems to be no reason to assume any change in this pattern, given the limitation to persons of "college age."

The combination of these projections of "special" populations with those of the civilian, non-college population aged 0 to 59 years is the final projection of population, by region of residence, for the year 2000. This distribution is shown in Table 6 , which compares the regional population distributions of 1977 and 2000. The results are not surprising, in that they suggest continuing relative growth in the South and West, and continuing relative decline in the North. In general, the most heavily industrialized portion of the nation-New York-New Jersey, Pennsylvania, and the Great Lakes region (II, IIIA, and IV, respectively) seem likely to experience the least growth of population. On the other hand, relative growth should be the greatest in the Southern Mid-Atlantic, Southeast, and Southern Pacific Coast regions (IIIB, IV, and IX). These regions may be characterized as having a present industrial mix which will be favorably affected by the changes in industrial composition inherent in low rates of fertility, as well as including many of the states (Florida, Arizona, Nevada, and California) favored for retirement and climate oriented migration. 
TABLE 6

Projected Population by Age, Race, and Region: 2000 (thousands)

\begin{tabular}{|c|c|c|c|c|c|c|c|c|c|c|c|c|c|}
\hline & I & II & IIIA & IIIB & III & IV & V & VI & VII & VIII & IX & $\mathrm{X}$ & Total \\
\hline No. Households & 5,840 & 10,948 & 5,051 & 7,066 & 12,117 & 19,382 & 20,859 & 10,892 & 5,182 & 2,958 & 15,099 & 3,622 & 106,898 \\
\hline \multicolumn{14}{|l|}{ Total: } \\
\hline $0-9$ & 1,609 & 2,979 & 1,326 & 2,023 & 3,348 & 5,143 & 5,967 & 2,973 & 1,416 & 817 & 4,397 & 1,007 & 29,657 \\
\hline $10-17$ & 1,456 & 2,659 & 1,203 & 1,970 & 3,173 & 4,774 & 5,436 & 2,744 & 1,283 & 779 & 4,023 & 918 & 27,247 \\
\hline 18-14: Military & 27 & 31 & 7 & 123 & 130 & 242 & 47 & 142 & 38 & 45 & 223 & 50 & 976 \\
\hline College & 332 & 590 & 233 & 273 & 505 & 692 & 933 & 489 & 262 & 176 & 610 & 168 & 4,759 \\
\hline Other & 900 & 1,674 & 735 & 1,098 & 1,834 & 2,848 & 3,305 & 1,643 & 793 & 455 & 2,472 & 567 & 16,491 \\
\hline TOTAL & 1,257 & 2,295 & 975 & 1,494 & 2,469 & 3,782 & 4,285 & 2,274 & 1,093 & 676 & 3,305 & 785 & 22,225 \\
\hline 25-34: Military & 15 & 17 & 4 & 66 & 70 & 131 & 25 & 77 & 20 & 24 & 120 & 27 & 526 \\
\hline Other & 1,829 & 3,372 & 1,527 & 2,361 & 3,888 & 5,906 & 6,853 & 3,423 & 1,608 & 933 & 4,973 & 1,136 & 33,924 \\
\hline TOTAL & 1,844 & 3,389 & 1,531 & 2,427 & 3,958 & 6,037 & 6,878 & 3,500 & 1,628 & 957 & 5,093 & 1,163 & 34,450 \\
\hline 35-44: Military & 8 & 9 & 2 & 35 & 37 & 68 & 13 & 40 & 11 & 13 & 63 & 14 & 276 \\
\hline Other & 2,230 & 4,045 & 1,795 & 2,936 & 4,731 & 7,199 & 8,209 & 4,144 & 1,906 & 1,162 & 6,058 & 1,384 & 41,068 \\
\hline TOTAL & 2,238 & 4,054 & 1,797 & 2,971 & 4,768 & 7,267 & 8,222 & 4,184 & 1,917 & 1,175 & 6,121 & 1,398 & 41,344 \\
\hline $45-54$ & 1,887 & 3,469 & 1,604 & 2,619 & 4,222 & 6,282 & 7,143 & 3,605 & 1,715 & 1,037 & 5,302 & 1,209 & 35,875 \\
\hline $55+$ & 3,109 & 6,064 & 2,909 & 3,100 & 6,009 & 10,710 & 10,160 & 5,740 & 2,806 & 1,536 & 7,071 & 1,882 & 55,089 \\
\hline TOTAL & 13,402 & 24,909 & 11,345 & 16,604 & 27,947 & 43,995 & 48,091 & 25,020 & 11,858 & 6,977 & 35,312 & 8,362 & 245,877 \\
\hline
\end{tabular}




\section{TABLE 7}

Demographic Indicators for DOE Regions: 2000

\begin{tabular}{|c|c|c|c|c|c|c|c|c|c|c|}
\hline & Percent $\mathrm{C}$ & $\begin{array}{l}\text { White } \\
\text { and } \\
\text { Other }\end{array}$ & $0-2000$ & $\begin{array}{l}\text { Percent } \\
0-17\end{array}$ & $\begin{array}{c}\text { Percent } \\
\text { Civilian, } \\
\text { Noncollege } \\
18-54\end{array}$ & $\begin{array}{l}\text { Percent } \\
55+\end{array}$ & $\begin{array}{l}\text { Percent } \\
\text { Military }\end{array}$ & $\begin{array}{l}\text { Percent } \\
\text { College }\end{array}$ & $\begin{array}{c}\text { Percent } \\
\text { Black }\end{array}$ & $\begin{array}{l}\text { Ratio of civilian } \\
\text { noncollege popu } \\
\text { lation aged } \\
18-54 \text { to jobs }\end{array}$ \\
\hline I - New England & 13.1 & 10.8 & 80.7 & 22.9 & 51.1 & 23.2 & 0.4 & 2.5 & 5.2 & .958 \\
\hline $\begin{array}{c}\text { II - New York/ } \\
\text { New Jersey }\end{array}$ & -1.8 & -9.2 & 22.1 & 22.6 & 50.4 & 24.3 & 0.2 & 2.4 & 14.4 & .969 \\
\hline IIIA - Pennsylvania & -3.8 & -4.2 & 0.2 & 22.3 & 49.9 & 25.6 & 0.1 & 2.1 & 9.0 & .966 \\
\hline $\begin{array}{l}\text { IIIB - Southern } \\
\text { Mid-Atlantic }\end{array}$ & 42.9 & 42.0 & 46.7 & 24.0 & 54.3 & 18.7 & 1.3 & 1.6 & 19.8 & .978 \\
\hline III - Mid-Atlantic & 19.4 & 17.3 & 32.2 & 23.3 & 52.5 & 21.5 & 0.8 & 1.8 & 15.4 & .970 \\
\hline IV - Southeast & 38.1 & 46.3 & 7.5 & 22.5 & 50.5 & 24.3 & 1.0 & 1.6 & 16.4 & .962 \\
\hline V - Great Lakes & 9.2 & 4.6 & 56.4 & 23.7 & 53.0 & 21.1 & 0.2 & 1.9 & 12.7 & .977 \\
\hline VI - Southwest & 23.0 & 22.4 & 26.4 & 22.8 & 51.2 & 22.9 & 1.0 & 2.0 & 15.3 & .962 \\
\hline VII - Plains & 5.5 & 2.3 & 82.4 & 22.8 & 50.8 & 23.7 & 0.6 & 2.2 & 7.1 & .938 \\
\hline $\begin{array}{l}\text { VIII - Rocky } \\
\text { Mountains }\end{array}$ & 25.1 & 23.3 & 141.5 & 22.9 & 51.4 & 22.0 & 1.2 & 2.5 & 2.8 & .947 \\
\hline $\begin{array}{l}\text { IX - Southern Pacific } \\
\text { Coast }\end{array}$ & 53.6 & 46.2 & 161.5 & 23.8 & 53.3 & 20.0 & 1.2 & 1.7 & 11.0 & .954 \\
\hline $\begin{array}{l}\text { X - Northern Pacific } \\
\text { Coast }\end{array}$ & 28.3 & 27.2 & 95.4 & 23.0 & 51.4 & 22.5 & 1.1 & 2.0 & 2.5 & .956 \\
\hline Total & 21.0 & 19.0 & 36.9 & 23.1 & 52.9 & 22.4 & 0.7 & 1.9 & 12.6 & .977 \\
\hline
\end{tabular}




\section{IMPLICATIONS OF THE PROJECTIONS}

The purpose of this concluding section is to comment briefly upon the implications of the projections derived and presented in the foregoing sections. In particular, this section will dwell upon whether any obvious economic or social problems seem likely to arise in any region as a result of economic or demographic changes projected to occur between the present and the remainder of the century. The discussion in this section will be based upon the following: rates of population growth, the composition of the population, and the industrial mix. The latter will be the basis for a discussion of differences in the level of earnings among regions.

Table 7 contains basic material on the demographic indications for DOE regions in the year 2000 , as a result of the projections made here. It is clear that several regions will experience relatively rapid rates of population growth during the remainder of the century-these include the Southern Mid-Atlantic (IIIA), the Southeast (IV), and the Southern Pacific Coast (IX). In addition, the remaining regions of the South (VI) and West (VIII,X) will grow at rates slightly above the national total. On the other hand, growth should be comparatively slow in the Northeast (I, II, IIIA) and North Central (V, VII) regions; in particular, both the New York/New Jersey and Pennsylvania areas are projected to experience absolute losses of population during this period.

It may be argued that there are economic and social disruptions inherent in both extremely rapid and extremely slow rates of population growth. Rapid population growth can put great pressures on existing infrastructure-schools, roads, hospitals, transportation facilities, and the like. On the other hand, extremely slow growth or population decline can lead to financial problems for the affected jurisdictions - tax bases may well be exhibiting little or no growth, but demand will continue to exist for various types of public facilities. Consider particularly, in this light, the demographic structure of the New York/New Jersey and Pennsylvania regions. Not only are these regions projected to experience population decline, but both will have a relatively unfavorable age structure-note the proportion of older persons residing in these regions, and the comparatively low proportion of persons of prime working age. Despite its high rate of growth, a similar demographic pattern emerges in the Southeast. Here, though, there are two somewhat alleviating factors; first, a relatively substantial portion of the older population in this region will represent immigrants to the region, attracted to it for retirement purposes. Given that migration of this type is selective of economic characteristics (that is, those comparatively well off are most likely to move), there should not be excessive problems from this immigration, although medical facilities might be under some pressure. Second, the comparatively low proportion of persons of primary working age is particularly the result of the relatively large number of military personnel living in the region. They will add somewhat to the economic strength of the region, through expenditures and possibly income tax payments, but will not put any particular pressure on locally provided public services (in the case of schools, federal 
funds are provided to school districts with large shares of military dependents enrolled).

On the other side of the coin, three regions - the Southern Mid-Atlantic (IIIB), the Great Lakes (V), and the Southern Pacific Coast (IX) are projected to have considerably larger proportions of school-aged children than is true nationwide. Again, this is the result of differing proportions of young adults in the regional populations, and not the result of any assumed regional differences in age-specific fertility. While the absolute numbers of children in these regions by the end of the century will not be very much larger than at present, due to the underlying assumption of sustained low fertility, some pressures on existing facilities are likely to arise in these regions - certainly, such pressures will be greater here than elsewhere.

Despite our assumption that much of the migration flows over the next two decades will be in response to differential rates of employment opportunity, there may be problems for several regions in terms of the adequacy of labor supply. The demand for labor, by region, has been the principal force in our formulation of regional projections. However, the computation of the ratio of labor demand to potential supply, defined as civilian, non-college population aged 18-54, suggests that in many regions, (notably New England, the Plains, and all of the West) imbalances might be relatively severe. The prospects for national problems in this regard have been noted elsewhere (Reynolds, 1979; Serow, 1980a); here it need only be added that this shortage may be relatively more severe in some regions than in others.

The final point we wish to make is the effect of changes in industrial composition for regions and their effects on the level of earnings and income. Although recent analyses have concluded that the failure to adjust for regional differences in cost of living has tended to exaggerate regional differences in earnings (Coelho and Ghale, 1971; Bellante, 1979), there still remains the need to establish what, if any, differences in earnings and income will exist among regions as a result of the demographic and economic changes discussed in this paper. This comparison will be made by utilizing the differences in industrial composition, and the assumption that relative wage levels among industries will remain fixed at their observed 1970 levels (U.S. Bureau of the Census, 1973a). The result is an overall index of earnings, by region, for the year 2000 (Table 8). The results suggest a considerable narrowing of earnings differentials, thus continuing the trend which has been evident for the past several decades. It should be noted that the approach used to generate these data implicitly fixes relative earnings at their 1970 levels. No attempt is made here to account for regional differentials in the cost of living in determining the relative level of money income. In addition, these data result solely from changes in industrial composition. Other factors, such as regional productivity differentials, have not been considered. It is quite possible that the introductions of such a variable could alter these results. It probably should be noted that the relatively poor performance of the West is largely 
TABLE 8

Index of Relative Earnings by DOE Region: 2000

(U. S. $=100.0)$

\begin{tabular}{lr}
\hline I - New England & 100.26 \\
II - New York/New Jersey & 101.46 \\
IIIA - Pennsylvania & 99.48 \\
IIIB - South Mid-Atlantic & 102.27 \\
III - Mid-Atlantic & 101.19 \\
IV - Southeast & 99.15 \\
V - Great Lakes & 100.40 \\
VI - Southwest & 100.30 \\
VII - Plains & 98.72 \\
VIII - Rocky Mountains & 99.34 \\
IX - Southern Pacific Coast & 99.15 \\
X - Northern Pacific Coast & 98.24
\end{tabular}

due to the relatively large share of personal service and agricultural employment found in this region. Similarly, the relatively good performance of the South Mid-Atlantic region is almost solely due to the very heavy concentration of federal workers in this region.

In conclusion, it seems likely that the economic and demographic changes which occur as a result of a period of sustained low fertility will imply different sorts of economic and social difficulties for different regions. Some will face problems caused by slow population growth or population decline, largely caused by net outmigration, thus creating a relatively unfavorable age composition. Other regions will face problems of the reverse sort, namely relatively rapid population growth, again largely through inmigration. By and large, it seems that recent regional population shifts, from the North and North Central states to those of the South and West, will persist.

Such a conclusion is, of course, hardly a surprising one in light of recent demographic history. Again, it should be recalled that the process of population redistribution, like that of population growth in general, possesses a built-in momentum which, once underway becomes difficult to halt. At the present, there seems to be no reason for market forces to move in such a way over the next twenty years to cause a reversal of these redistributional trends. Once a pattern of sustained industrial growth begins to emerge in a region, other industries become attracted to that region. The newcomers may be suppliers or competitors of the first industry, but in any event, the economics of industrial location usually favor such a development pattern. Additionally, the attraction of new workers to the region (to work for the new industries) adds stimulus to growth in the service and construction industries.

In all of these contexts, it seems that further growth of the South and the West, at the "expense" of the North, is inevitable. Our purpose here is not 
to speculate on those factors initially responsible for this growth (see Serow, 1980b, for such an analysis of the South). The momentum of growth is fully underway in these regions and industries which seem most likely to experience relatively rapid growth over the coming two decades are already located, by and large, in the "Sunbelt" to a disproportionate extent. Consequently, additional population and industrial growth seems most likely to be concentrated in these regions in the near future. This tendency is reinforced by the fact that the South and West contain the majority of locations most favored by those moving for retirement purposes; furthermore, the South and West continue to contain a substantial proportion of the nation's military population.

The extent to which these trends could be reversed, or even slowed down, by federal regional growth policies is questionable. While there has been considerable speculation on the effectiveness, appropriateness, and timeliness of such policies (Jusenius and Ledebur, 1977), it remains to be seen whether the nation as a whole would benefit from measures designed to stimulate growth in the North at the "expense" of the South and West. The pains of growth or no-growth are likely to continue to be felt across the nation to a degree similar to those of the past decade. More productive policy measures might aim at coping with what is likely to be demographic and economic reality, rather than engaging in a quixotic effort to avert or blunt that which seems inevitable.

\section{REFERENCES}

Ashby, L. D. and D. W. Cartwright. n.d. Regional Employment by Industry, 1940-1970. Washington: U. S. Department of Commerce, Bureau of Economic Analysis.

Barsby, S. L. and D. R. Cox. 1975. Interstate Migration of the Elderly. Lexington: Lexington Books.

Bellante, D. 1979. "The North-South Differential and the Migration of Heterogeneous Labor." American Economic Review 69: 166-175.

Coelho, P. R. and M. A. Ghali. 1971. "The End of the North-South Wage Differential." American Economic Review 61: 932-937.

Fullerton, H. N. and P. O. Flaim. 1976. "New Labor Force Projections to 1990." Monthly Labor Review 99:3-13 (December).

Jusenius, C. L. and L. C. Ledebur. 1977. "A Myth in the Making: The Southern Economic Challenge anc Northern Economic Decline." In E. B. Liner and L. K Lynch, eds., The Economics of Southern Grouth. Research Triangle Park: Southern Growth Policies Board.

Long, J. F. 1976. "Interstate Migration of the Armed Forces." Paper presented at the annual meeting of the Southern Sociological Society, Miami.

Long, L. H. and K. A. Hansen. 1979. "Reasons for Interstate Migration: Jobs, Retirement, Climate, and Other Influences." Current Population Reports, Series P-23, no. 81.

Longino, C. F. 1979. "Going Home: Aged Return Migration in the United States, 1965-1970." Journal of Gerontology 34: 736-745.

Reynolds, C. W. 1979. "Labor Market Projections for the United States and Mexico and their Relevance to Current Migration Controversies." Food Research Institute Studies 17: in press.

Serow, W. J. 1976. "The Role of the Military in Net Migration for States." Review of Public Data Use 4: 42-48 (May).
- 1978. "Return Migration of the Elderly in the USA: 1955-60 and 1965-70." Jourmal of Gerontology 33: 288-295.

- 1980a. "Demographic and Economic Considerations for Future Retirement Policy." Policy Analysis 6: forthcoming.

1980b. "An Economic Approach to Population Change in the South." In D. L. Poston and R. H. Weller, eds., The Poprulation of the South: Structure and Change in Social Demographic Context. Austin: Universiy of Texas Press.

Serow, W. J. 1981. "Alternative Demographic Futures and the Composition of the Demand for Labor." Research in Population Economics 3: 209-223.

Steahr, T. E. and R. A. Lowe. 1975. Patterns and Trends of College and University Student Migration in the United States. Storrs: University of Connecticut, Agricultural Experiment Station.

U.S. Bureau of the Census. 1973a. Industrial Characteristics. Washington: Government Printing Office.

. 1973b. Mobility for States and the Nation. Washington: Government Printing Office.

. 1973c. Sources and Structure of Family Income. Washington: Government Printing Office.

1977. "Projections of the Population of the United States: 1977 to 2050." Current Population Reports, Series P-25, no. 704.

1979a. "Illustrative Projections of State Populations by Age, Race, and Sex: 1975 to 2000." Current Population Reports, Series P-25, no. 796.

$1979 \mathrm{~b}$. Projections of the Number of Households and Families: 1979 to 1995." Current Population Reports, Series P-25, no. 805.

. 1979c. "School Enrollment - Social and Economic Characteristics of Students, October 1978." Current Population Reports, Series P-20, no. 346. 